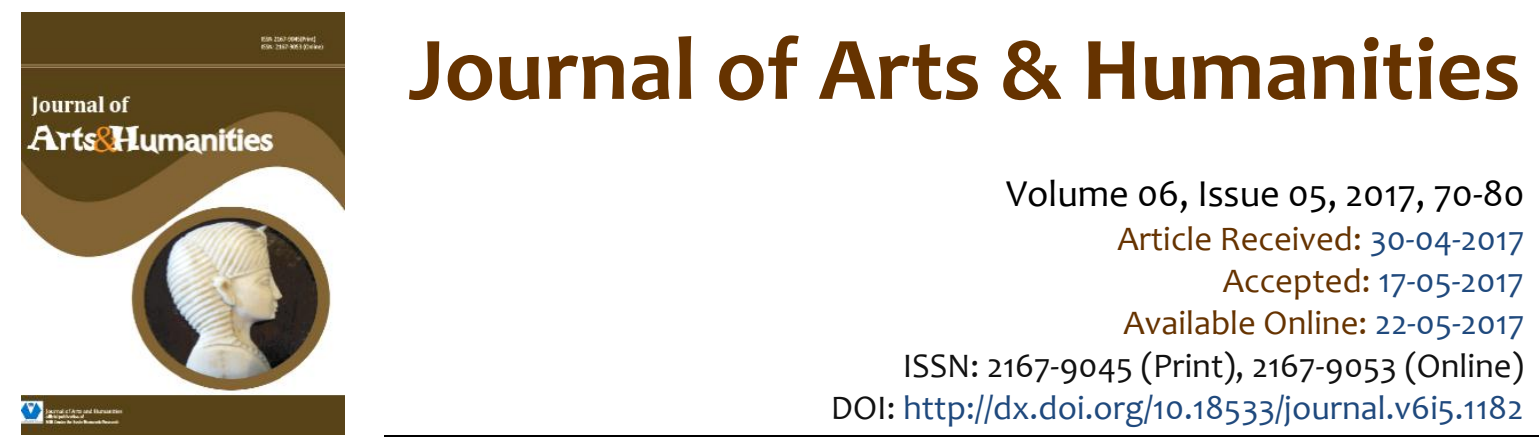

\title{
Oathing, Law and Order in Colonial Gusiiland
}

\author{
Jackson Ondong'a Maranga'
}

\begin{abstract}
Though looked upon as informal and backward, oath-taking practices were employed in the administration of law and order among the Gusii people of Kenya during the colonial period. This chapter examines the role of oath-taking in the maintenance of law and order in colonial Gusiiland. More specifically, the chapter examines (1) the various types of oaths among the Gusii people; (2) the contribution of these various forms of oaths to the maintenance of law and order; (3) the relationship between oaths and gender among the Gusii people and (4) the impact of colonial administration on Gusii oath-taking ceremonies. Data which informed this chapter was obtained from archival sources as well as secondary literature.
\end{abstract}

Keywords: Gusii, Law, Oath-taking, Order.

This is an open access article under Creative Commons Attribution 4.0 License.

\section{Introduction}

Informal traditional or indigenous forms of dispute resolution in Africa predate the advent of colonialism. Communities resolved conflicts amicably through informal negotiations and mediation, and parties were reconciled by elders. This model of dispute resolution laid emphasis on brotherhood and unity within the community rather than individual interests (Onsongo 2016). The immediate former Chief Justice Willy Mutunga is on record as having recognized the important role that traditional mechanisms of resolving conflict can play in society (Onsongo 2016). Usually regarded as informal and backward, traditional mechanisms of restoring law and order have been known to have increased access and delivery of justice to the people in precolonial Africa. These mechanisms have a huge potential for enhancing access to justice, strengthen the rule of law and bring about development among communities, hence their recognition. They also promote and achieve social justice and inclusion, particularly amongst groups that have been excluded from the formal justice system (Hunter 2011).

The establishment of colonial rule in Kenya, as elsewhere in Africa, led to the imposition, on Africans, of a western legal tradition premised upon an Anglo-American jurisprudential. African values, norms and beliefs, which provided the normative and undergirding framework for conflict resolution, were severely

\footnotetext{
${ }^{1}$ Post-graduate student, Jaramogi Oginga Odinga University, Kenya.
} 
weakened, undermined and disregarded (Maigua 2012; Kariuki 2015, Onsongo 2016, Freddie and Koketso 2013). Though viewed as more superior and better, the modern institutions of administering law and order in Kenya have been found to be grossly flawed due to massive cases of corruption (Maraga 2016). It is for this reason that it has been held that "there is deep rooted mistrust of the formal justice system" (Macfarlane 2007). Writing about flaws within the modern justice systems, Akeredolu (2016) notes that the lower-class person is (1) more likely to be scrutinized and therefore to be observed in any violation of the law, (2) more likely to be arrested if discovered under suspicious circumstances, (3) more likely to spend the time between arrest and trial in jail, (4) more likely to come to trial, (5) more likely to be found guilty, and (6) if found guilty, more likely to receive harsh punishment than his middle- or upper-class counterpart.

Due to socio-economic and political changes which societies have undergone, the traditional justice is ill suited to be relied upon as a mechanism of administering law and order. There is need to reconcile the two legal landscapes. By focusing on the role of oaths in the administration of law and order among the colonial Gusii people of Kenya, this chapter attempts to make a contribution towards the understanding of the need to reconsider the importance and effectiveness of traditional institutions of administering law and order compared to and alongside modern legal institutions.

\section{Methodology}

A historical research design was applied in writing this chapter. Historical research design takes into consideration the exploration, explanation and understanding of past phenomenon from data already available. It helps the researcher to arrive at conclusions about causes, trends and effects of past phenomenon in order to explain the present and, at the same time, predict and control the future (Munge, Ndeda and Okuro 2016). This design was found to be suitable for this chapter because the study was focused on comparing the historical differences between old and contemporary mechanisms of administering law and order in society with a focus on oath-taking among the Gusii in the colonial period. More importantly, the study examines the historical changes, impact and importance of oath-taking practices in the maintenance of law and order in colonial Gusiiland. Data which was used to write this chapter formed part of the mega study which the author undertook for his master's degree on the transformation of colonial law and order among the Gusii people. Both archival and secondary sources of data were used to inform the writing of this chapter. Archival data was accessed at the Kenya National Archives while secondary data was accessed from various public and private university libraries in Kenya.

\section{Oath-taking: Conceptual and theoretical framework.}

In the contemporary world, and according to Professor James Endell Tyler, oaths are used in adjudicatory processes as "an outward pledge given by the juror that his attestation [or promise] is made under an immediate sense of his responsibility to God (Quoted in Milhizer 2009:2)." Parties in a legal suit are made to swear by the Almighty God before commencement of judicial process. Before the spread of Christianity and Islam, world's dominant religions, precolonial African societies applied oathing practices in adjudicatory process. This is bearing in mind that oaths, in this societies, acted as a guarantor of truth by guarding against testimonies which were false by juxtaposing the individual's dishonest motive against his sense of moral culpability and fear of divine punishment. Thus, while the form and meaning of oaths vary across societies and have changed over time, oathing practices have remained to be natural and universal custom that has been found virtually everywhere human society exists (Milhizer 2009). One such society where oaths have been noted to have played a significant role in the administration of law and order is among the Gusii people of Kenya. In the colonial period, this community was administered under the South Nyanza District (Silberschmidt 1999, Were and Nyamweya 1986, Maxon 1989, Ochieng 1974).

From a theoretical perspective, oath-taking practices played a functionalist role in society in so far as they helped maintain or restore equilibrium. The theory of structural functionalism holds the view that society 
always strives to exists at an equilibrium and whenever this equilibrium is threatened, there are institutions which help to restore it. Society, is thus composed of various institutions which function independently and interdependently to restore equilibrium or harmonious co-existence among members of a society (Brock-Utne 2001). One of the strands of structural functionalism theory is the social capital theory which helps to explain and contribute to the understanding of how society functions. explains the formation of communal societies and the attendant social ties that bind them together. Traditional conflict resolution mechanism is a social capital, defined as the "capability of social norms and customs to hold members of a group together by effectively setting and facilitating the terms of their relationship... sustainability facilitates collective action for achieving mutually beneficial ends" (FredMensah, 2005:1).

Traditional mechanisms of administering law and order symbolized a healing process in which all stakeholders contributed positive energy which was driven towards the restoration and re-building of social harmony. According to the social capital theory, legal institutions exist with the function of either preventing a breakdown in social harmony or to restore that harmony (social ties) when it eventually breaks down (Choudree 1991). Without strong social ties, communities could not exist and function effectively. Even in serious cases such as murder, the threat of excommunication from the society, and therefore exclusion from social ties, ensured that potential wrongdoers thought about and refrained before wrongdoing.

It is against this background that we explain and understand the function that oath-taking played among the Gusii people in precolonial Kenya. Oath-taking practices among the Gusii was part of a wellstructured, time-proven social system geared towards reconciliation, maintenance and improvement of social relationships. As part of customary law, oath-talking practices helped the people to "to restore a balance, to settle conflict and eliminate disputes" (Choudree, 1999:1). Oath-taking practices, as applied in the administration of law and order had various advantages which made it workable. Firstly, the practice was relatively informal and thus, less intimidating. Secondly, the people who applied it or to whom it was applied were more at ease in a familiar environment. Thirdly, oath-taking practices were sacred because invoked the presence of God, the spirits, ancestors, family and neighbours (Mbiti, 1991). Thus, such practices were more binding and taken seriously by those who partook of them. On a general note, indigenous conflict resolution mechanisms focused on the principles of empathy, sharing and cooperation in dealing with common problems which underline the essence of humanity (Murithi, 2006).

Thus, traditional mechanisms of administering law and order in Gusii, through oath-taking practices, should be understood in their social context which involves, as Brock-Utne (2001:6) has observed, the "values and beliefs, fears and suspicions, interests and needs, attitudes and actions, relationships and networks..." The immediate objective of traditional mechanisms of resolving conflicts in society was the amending of broken or damaged relationship, rectifying wrongs, and restoring justice". In addition, such mechanisms ensured full integration of parties into their societies again. The effectiveness of the process and sustainability of the outcomes, generally, are attributed to such factors as simplicity, participatory nature, adaptable flexibility, complete relevance, and comprehensiveness (Brock-Utne, 2001).

Oath-taking was, like other mechanisms of administering law and order, deeply rooted and embedded in the inner system of indigenous (African) culture and customs of the traditional societies (Freddie and Koketso 2013:49). These types of non-state justice systems are often complex and sophisticated and have historically provided a complete justice alternative. They represent the continuity of traditional customs of dispute resolution and are less likely than overt political alternatives to be seen as a threat to the authority of the state. Instead, the intellectual elite tends to dismiss them as unsophisticated "village processes" which are unimportant in the development of a "modern" society, and a throw-back to the customs practiced in the country of origin, and inappropriate in a new and different context (Macfarlane 2007).

Even though African customary laws were retained, promoted and encouraged during the colonial rule, such laws underwent some transformation. And when they were applied, it was in favour of the colonial 
establishment (Killingray 1986). Thus, oath-taking practices were applied in colonial Gusiiland during the colonial period because they were not a danger to colonial establishment and, also, they led to better results in situations where the modern English law practice had failed. In a Traditional Court in colonial Gusiiiland, a person was tried by his village men and women and as a result there was no gap between him or her and the court. It was also difficult to draw a clear distinction between law, on the one hand, and public morality on the other (Freddie and Koketso 2013). It is, however, imperative to state that the lack of separation of powers did not mean that traditional leaders were not impartial because they were part of the executive arm of government. This was so because the judicial process was mainly aimed at mediation and reconciliation rather than categorically finding for or against a litigant. Therefore, if an individual committed an offence the whole group was involved and every member was liable, not as an individual but as part of the group or clan that committed the wrong.

In colonial Kenya, the application of oathing in the administration of law and order among the Gusii people was viewed as constituting customary law. Customary mechanisms of administering justice have been described as informal, non-state, non-official or non-formal justice systems. Customary oathing practices, for a long time during the colonial period, operated at the periphery of the formal justice system (Forsyth 2007). In Kenya, informal justice systems have been incorporated in law, subject to some limitations. The effect of this incorporation is yet to be seen. The relationship between formal and informal legal landscapes oscillates between recognition and adoption by the State on one end, and proscription and suppression on the other (Macfarlane 2007).

\section{Oaths, law and order among the Gusii}

The importance of oathing in Gusii society is attested to by the numerous oathing practices which existed in the old days. This oaths and their functions in Gusii society are discussed in the next section.

\section{(a) Oaths which were meant to establish the truth in a dispute}

The establishment of the truth is a key element in the administration of justice. In most cases, those charged with administering justice are confronted with the problem of establishing the truth. Whereas, witnesses may be called upon to help establish the truth, there arises a situation when witnesses are absent or not willing to witness. Among the Gusii people, among the disputes which arose and which needed first and foremost to establish who in the dispute was speaking the truth involved cases of debts. The "omotembe" oath was usually taken by parties disputing about a debt. The parties took off clothes. The plaintiff or appellant would then seizes the "omotembe" tree (Erythrina Abissica) and challenges the defendant, swearing that his own claim was correct. He was followed by the defendant or respondent who denied the claim, or alternately the defendant may refuse, if he considers that he is not justified in being forced to take such an oath. In omotembe oath, the tree which was used needed to be a living one and the parties would stand at its foot holding either the trunk or branch, (Kenya National Archives, DP/18/13). Repercussions, including death or bad omen, were expected to befall whoever bore false witness.

Omotembe tree was also used in the "ekeore" or the skull oath. This oath was rare owing to the difficulty of obtaining a skull. However, and in most cases, the skull of an enemy who had been killed and his skull left to decay above the ground would be used. This oath was commonly used in debts of any sort, and other quarrels such as assault claims. The plaintiff or complainant first holds the skull in his hand and challenges the defendant and his family if he lies. The defendant or accused then holds it and challenges the plaintiff in the same manner. Before the skull is used, two flowers of the "omotembe" tree are stitched into the empty eye-holes of the skull, (Kenya National Archives, DP/18/13).

Land disputes constituted another set of cases which called for establishing truths. Whenever parties disputed over ownership of a piece of land, several oathing practices were performed to establish who the true owner of the land in question was. These oaths were the "Orosiaga" "Omoega" and "Orokono" 
tree oaths. During litigation in land cases, an aggrieved party would bring a branch or stalk of any of the above plants to the land in dispute and either throw it on the land or strike the soil with it saying "may the party who states lies perish together with his family". The other party does the same thing. If both parties take the oath the matter is then treated as arbitration and the hearing adjourned to await the results of the oath. If one of the parties refuses to take the oath the council of elders may assume that his claim was a false one and may award the disputed land to the other party, (Kenya National Archives, DP/18/13).

Land disputes in Gusiiland were numerous and taken seriously by village, clan elders as well as the paramount chief. Equally interesting is the fact that land disputes invited a number of oath-taking ceremonies which served as a means of resolving them (land disputes). Rigio oath involved the breaking of an old pot in a disputed land, (Kenya National Archives, DP/18/13). This oath was not encouraged but only used in airtight situations. If the aggrieved party felt that he had some substantial rights in the land in dispute which the elders awarded to the other party, then such an aggrieved party could, if he considered the situation desperate, take the rigio oath. The land on which the rigio oath had been taken was considered cursed and neither parties nor their close relatives could cultivate it. Only a person from a different clan who was not related to the disputants could cultivate it. It was also regarded as bad, under the rigio oath, if one of the disputants hit the land with a branch of one of the trees namely omotembe, omwogia, orosiaga, omobamba or orokono. Ekuruki oath, on the other hand, involved the beating hard of a skin of the kind used to cover a woman's navel (Ekuruki) on a disputed land. Finally, amasagisa oath involved a collection of several plants including "amenyinga and "omobeno" trees, "chintamame "flowers, orosiaga (nappier grass) and the skeleton of a dead dog, all carried in one basket and sent to a debtor's home at night if he refused to pay a debt. This kind of oath was used by poor people only, (Kenya National Archives, DP/18/13).

\section{(b) Oaths which were meant to establish the accused/suspect in a case}

In contemporary times, the administration of justice may be hampered if the accused/suspect is not known. In contemporary Kenya, police from the Criminal Investigation Department (C.I.D) are called and relied upon to establish the accused/suspect through thorough investigations (Foran 1962). Among the Gusii, Orosanganga oath or the nappeir grass oath was employed to establish the suspect. In for example, somebody's cow had been killed and the accused unknown, orosanganga oath was employed. This oath consisted of eating the flesh of the dead animal. Flesh was cut from the actual injury on the body of the animal and stitched on a sharpened piece of "Orosanganga" (nappier grass) stalk and which the owner of the animal gave pieces of flesh to the suspected killer or killers, challenging him/them to it (Kenya National Archives, DP/18/13).

Apart from disputes involving a dead animal, there were also disputes over ownership of a living animal. Different people would claim ownership of a living animal. To establish who the accuser and the accused were in such a dispute, the Okobutora Ogoto oath was employed. In such disputes, the party in whose village the animal was found may hold its horn while the plaintiff cuts its right ear with a spear (endobo). Parties in dispute challenge each other when the animal shakes the ear throwing blood on them. The animal is then left to return to the village in which it was found, the piece cut from the ear being taken by the plaintiff for retention and to await for the result of the oath. This piece of ear is later produced at a cleansing (ogosonsorana) feast, if either party has any trouble or deaths in his family (Kenya National Archives, DP/18/13).

Another Gusii oathing ceremony which was performed to establish the accused was the amaera oath. This oath was used where arson had taken place and the suspect was unknown. The owner of the burnt house mixes some of the ashes of the burnt building with water or "amarwa" (native beer) and gives it openly to all people living adjacent, to be drunk on the site of the alleged arson. Whoever refuses to drink may be regarded as the offender and thereby ordered by the elders to pay for damage, (Kenya National Archives, DP/18/13). 
Yet, there was the "Amasangia" oath which was used in adultery disputes or sexual offences against females. The woman on whom the offence was committed stands naked with her legs wide open while the alleged offender is challenged to pass between them, publicly and also naked, carrying in his right hand a spear and in the left hand a native shield, (Kenya National Archives, DP/18/13).

\section{(c) Performance of deterrence oaths in colonial Gusiiland}

Law is not only meant to punish offender. An important element of law is to prevent certain offences. The Gusii people also performed oathing ceremonies whose main agenda was to deter would be offenders. When, for example, cattle thefts had been alarmingly on the increase in the late 1940s, in Kitutu Location, an oath of this type was performed to bring the practice to a bare minimal. This type of oath was reported upon by the chief of Kiutu Location. In his monthly report of May 1948, the chief of Kitutu Location states that:

Avery big baraza [public meeting] was held at Rigoma in the upper Kitutu which was attended by very many wazees [old men], young men and women. Names of more than 120 thieves were mentioned and recorded. About 70 such suspectants were called before the crowd. Each thief stood and was asked to confess. When every thief had confessed, the elders decided that they should make oaths. Some 12 old famous and honoured elders were chosen to establish this oath. Thieves were told to return in the crowd. Each of the12 elders selected stepped before the crowd and taking off his hat and said the following words which every man, woman and child applauded:that anybody who will attempt to steal from today onwards will be speared from front or back side if he tries to escape. At last an old blind man was called in, and twisted the grass saying that anybody who may break this by law will not move an inch before he is speared. When this had been done by the 2 elders and a blind man, everybody stood and cried as if a great man had died (Kenya National Archives, DP/1/13).

Indeed, the administration of the oath as stated above bore fruits. The chief of Kitutu Location, in his annual report covering the months of May-December 1949 states that “... an oath was performed between the elders and well known thieves in May. Since then, thefts in the location have decreased considerably... This good work was done through great help of local elders and some thieves who surrendered to keep good behavious as law-abiding citizens... (Kenya National Archives, DP/1/13).

The colonial administration had, since its establishment in Gusiiland, tried hard to stop cattle thefts without success. In 1913 or thereabout, for example, measures had been put in place "to stop the practice of Kisii building cattle villages [ebisirate] on their outskirts of their locations far away from tribal control. Such villages were undoubtedly utilized for hiding stolen cattle...," (Kenya National Archives, DC/KSI/1/2, South Kavirondo District Annual Reports; 1913-1923). By 1949, cattle thefts still presented a menace to the colonial administration to such an alarming extent that the Gusii resorted to oathing ceremonies.

\section{Oaths and gender in Gusiiland}

Silberschmidt (1999) has noted that the Gusii society was patriarchal in nature. Oaths, like rituals, were presided over by men. Mayer (1965) has observed that the Gusii performed rituals at home in the same setting in which all other activities took place, often with the patriarch as chief officer Mayer. LeVine (1966) observes that:

.... the homestead head was formerly the absolute ... and owner of all its property, with sole power to resolve all its internal difficulties, including intra-family homicide. The internal allocation of livestock and land was entirely in his hands, and he was also the principal performer of sacrifice to the ancestors.... There were generally accepted customs concerning allocation of property within the domestic group but if the homestead head chose to disregard them, no one within or outside the homestead could challenge his authority and the matter would wait until his death for the adjudication of other elders. He had the power of putting a curse on his adult sons, which would 
kill them or drive them mad unless rescinded after a public apology by the son. Everyone in the homestead was obliged to show difference to its head in their everyday behavior... (quoted in Silberschmidt 1999:35).

Gusii men were thus charged with the responsibility of resolving conflicts whether at the family level or clan level. Silberschmidt (1999) has observed that Clan loyalty passed from father to son, and all disputes were directly mediated through male family heads. Informally, and regardless of genealogy, the mature men of the neighborhood were collectively the neighborhood bosses. They would meet regularly as a clique to relax, drink beer and talk local business affairs. Local cases would be brought to them to be judged in accordance with Abagusii law which all adult men were supposed to know (Silberschmidt 1999). In the same vain, oathing practices, when and if they were used to resolve conflicts and disputes, were presided over by men mostly.

Authority however was rarely concentrated on the hands of one man. At the local neighborhood level (maiga) the authority to resolve disputes lay with elders (etureti and egesaku). Eureti were family elders while egesaku were clan elders (Kenya National Archives, DP/18/13). The etureti elders and the egesaku elders, adjudicated inter clan disputes, Brett L, (1968). Clan elders "Etureti and Egesaku" comprised of people of the same birth, family and ancestry derived laws which solved disputes of land inheritance, land adjudication among others (Mzee Omoke, O. I., $27^{\text {th }}$ December 2014; Ezekiel Ochari, O. I., $28^{\text {th }}$ December 2014).

We had certain oathing ceremonies which were meant for women only. One such oathing practice was called the "Okonyagora Omwana" Oath. In cases where the accused or defendant was a woman with unweaned child, the woman was made to lay the child on the ground and step over it denying the charge or claim. This serves as an oath to show that she did not do the crime. If she was lying the child would die. Women's love for their children was exploited in such oathing ceremonies. A woman would not let her own child and as such she would not be ready to tell a lie. Such oaths are were not taken by men, (Kenya National Archives, DP/18/13). However, oathing ceremonies which targeted women in Gusii society were very few.

As we have observed elsewhere in this chapter, women were also involved in oathing ceremonies which involved sexual offences such as rape. The "Amasangia" oath was used in adultery disputes or sexual offences against females. The woman on whom the offence was committed stands naked with her legs wide open while the alleged offender is challenged to pass between them, publicly and also naked, carrying in his right hand a spear and in the left hand a native shield, (Kenya National Archives, DP/18/13).

The Gusii society was highly patriarchal during the colonial period. The participation of women in Gusii oathing ceremonies attests to this fact. In most cases, it the Gusii council of elders (men) who were charged with the responsibility of administering oaths. There were two sets of council of elders in colonial Gusiiland namely Egesaku or Etureti. The only oath ceremonies which involved women are those of pregnancies out of wedlock. The pregnant woman would be involved in oathing ceremonies in order to establish the man responsible for the pregnancy. This is if the man denied responsibility.

Otherwise the accused and the accusers, in disputes which called for oathing practices, were mostly men. Thus, it is Gusii men who were involved in disputes. Women were expected to be dealt with either by their husbands or their fathers. Disputes involving women were considered to be, mostly, domestic in nature and did not warrant the attention of Gusii elders.

Women were brought up in such a way as to be obedient to their husbands or fathers. In Gusii society, women were not considered as full citizens. An offence to a woman was a regarded as an offence to either their fathers or husbands (Shaddle 2006). For these reasons, Gusii women's participation in oathing ceremonies was extremely limited. When they participated, they did so mainly as onlookers or as victims. 


\section{Impact of colonial administration on Gusii oathing practices}

Colonialism impacted on Gusii oathing practices in various ways. The colonial experience of Africa began in 1885 after the Berlin Conference, in which Africa was partitioned into European spheres of influence. With the arrival of the Europeans, various ethnic groups were combined within arbitrarily formed territories and subjected to European laws and institutions that operated along the lines of these newly created regions (Tobiko 2013). African customary laws and attendant institutions were thus greatly diminished as they were restricted in application to the extent allowed by formal, state-sanctioned laws.

Thus, Africa got a colonial legacy of legal pluralism or dual legal systems borne out of the effects of imposition of foreign laws of colonial powers. These imported foreign laws were applied with limited variations to account for local circumstances and the necessities of colonial rule. The net effect was to marginalize the application of pre-existing African customary law systems. Laws were made restricting the application of customary laws to matters of land disputes and personal law e.g., marriage, divorce, inheritance. Application of customary laws would also be subject to the 'repugnancy rule', that is, it should not contravene a sense of morality and justice as conceived in western world societies. Most Africans felt alienated from the imposed dual system of justice, as the foreign laws were not only culturally alien but also discriminative. There was a justice system for Africans and another for nonAfricans (Tobiko 2013).

The first impact was through a process which the colonial government referred to as detribalization. This is the process through which Africans lost touch with their tribal law and customs. Several factors contributed to this process. One of them was the acquisition of western education by the Africans/Gusii people. As more and more Africans went through the Western educational process, they lost touch with African norms which they referred to as uncivilizing and primitive. The second process which contributed to detribalization was the spread of Christianity. The establishment of colonial rule in Gusiiland provided a conducive environment of peace which led to rapid spread of Christianity. White missionaries discouraged Christian converts against engaging in their customs such as participating in pagan oathing practices, idolatry, wife inheritance and polygamy, among other things. The third impact of colonialism on Gusii customary law was migration of labour from Gusiiland to white farms and urban centers in search of paid work. The third one was the out-migration of Africans in search of employment. White farms and urban centers attracted male labourers from various ethnic communities. These settings, thus, became multicultural in nature. It was not possible for migrant laborers to subscribe to their specific cultural dictates. The result was increasing detribalization of migrant labourrers. When many of them went back to their rural settings, they had lost touch with their tribal customs due to either urban or multicultural influence.

\section{Weaknesses and strengths of Gusii oathing practices}

Uncircumcised boys, young men under age of 18 and unmarried girls were exempted from taking oaths (Kenya National Archives, DP/18/13). Aggrieved parties in a dispute were the only ones allowed to participate in the oaths. No oath was allowed to be administered in disputes concerning inheritance between related parties or disputes concerning "Emesuto" (a cow given to a nephew by an uncle). The word Emesuto originates from four short sticks of either "Omosocho" or "omorororia" trees which were cut and tied together with a string and given to a woman by her parents to take to her husband's home after her wedding. She later returned the same sticks (emesuto) to her home and in exchange is given a heifer or cow to take to her husband's home. The cow or heifer is known was the "Eng'ombe y'emesuto", (Kenya National Archives, DP/18/13).

In spite of the limitations and restrictions, Gusii oathing practices did not subject participants to agonizing ordeals as was the case in certain societies. Among a people called the Marghi, for example, an oathing ceremony called the Guti subjected participants to agonizing ordeals. Milhizer (2009) observes that the Guti ordeal represented the most solemn form of an oath, so feared that litigants had been known to 
confess to perjury rather than undergo it. Common among African tribes are oaths connected to trials by ordeal, which of course were also found throughout Western history (Milhizer 2009). Another example of an agonizing oathing ordeal which Milhizer (2009) refers to is the sasswood (or red water) ordeal. This was an extreme and often gruesome form of judicial oath outlawed in many places by government. The accused enters a circle of people with pots of liquid at the center. He invokes the name of God three times, asks for God's wrath if he is guilty, and drinks water that is so toxic that it reduces respiratory functions until breathing ceases. If the accused becomes nauseated, he is proclaimed innocent. If he loses self-control, he is proclaimed guilty and his body is cursed, stoned, often dragged, and repeatedly "lacerated" until death. If the accused escapes without injury, however, he is thought pure and his accusers are arraigned in the same ordeal. This ordeal was seldom administered in a fair manner (Milhizer 2009). The Gusii oathing practices disxussed in this chapter did not subject participants to such kinds of ordeals.

\section{Conclusion and policy recommendations}

The establishment of colonial administration and rule in Kenya led to the co-existence of traditional and "modern" forms of administering law and order among various Kenyan communities, the Gusii community included. Though co-existing, there has been a tendency to look down upon traditional forms of administering law and order. This is in spite of the inadequacies provided for by modern systems of law and order. Corruption among personnel charged with administering law and order has made modern law and order inadequate to meet the needs of society in terms of promoting justice and harmony in equal measure to all members of society. Those who have the money and power influence the outcome of court cases, always in disfavor of the have-nots. Thus, there is need for recompilation of both modern and traditional African systems of law and order. Even though there is tension between the two legal systems (formal and informal), they are not necessarily incompatible. Rather than being alien to liberal values, African traditional institutions have their own characteristics that could serve as a foundation to build democratic systems of government and promote justice for all. Particularly, African traditional institutions that largely work on principles of consensus and reconciliation could serve as a foundation to build a transformed democratic and just societal landscape in Africa. To achieve the goal of reconciling the two divergent systems of institutions, African legal systems need to adopt principles of legal pluralism, whereby the formal and informal institutions work together to achieve a transition to democracy and justice. This chapter, having demonstrated how oath-taking practices among the Gusii people during the colonial period helped to tackle cattle thefts, recommends that the government of Kenya should not just accommodate customary legal mechanisms in law but also establish a framework which ensures that customary law bears its impact among local communities in which it is practiced. This is bearing in mind the fact that informal justice institutions are oftentimes met with much more acceptance from and within the local communities. However, advocates of customary law admit that this option of administering law and order in society has limitations. This is because informal justice institutions function well within homogenous communities, but can create conflict in heterogeneous societies. They are effective in resolving conflicts on the community level, but not between individuals or groups and state institutions or other external actors. The Gusii people today need both modern/formal laws as well as customary law because they have been integrated to both the national and international landscapes. In addition, this chapter recommends that local communities should be properly included, as stakeholders, in establishing the legal framework under which customary legal systems operate. If this is not done, then the reform and strengthening of informal justice institutions and the creation of effective linkages with the state will fail.

\section{References}

Secondary sources

Akeredolu, D. 2016. Indigenous African criminal justice system for the modern world, Durham: Carolina Academic Press 
Brett, L. (1968): Changing traditions to meet current altering conditions': Customary law, African courts and the rejection of codification in Kenya, 1930-60, Cambridge University Press, United Kingdom.

Brock-Utne, B. 2001. "Indigenous Conflict Resolution in Africa". A draft presented to week-end seminar on Indigenous Solutions to Conflicts held at the University of Oslo, Institute of Educational Research, $23-24$ of February 2001.

Choudree, R. B. G. 1999. "Traditions of Conflict Resolution in South Africa". African Journal on Conflict Resolution. (1). http://www.accord.org.sa/publications/;/choudree.htm. Accessed $20^{\text {th }}$ May 2017.

E. Hunter, E. 2011. 'Access to justice: to dream the impossible dream? 'The Comparative and International Law Journal of Southern Africa, 44(3): 408-427.

Foran, Robert W. 1962. The Kenya police. London: Robert Hale

Forsyth, M. 2007. 'A Typology of Relationships between State and Non-State Justice Systems,' Journal Legal Pluralism \& Unofficial Law

Freddie, K. and Koketso, M. 2013. 'Law and traditional justice system in South Africa: A hybrid of historical and constitutional discourse', Journal of Global Peace and Conflict, 1(1): 49-65.

Fred-Mensah, B. 2005. "Nugormesese: An indigenous basis of social capital in a West African Community". $1 \mathrm{~K}$ Notes, No. 86, November. World Bank. Accessed at http://www.worldbank.org/afr/ik/default.htm. Accessed 19th May 2017.

Kariuki, F. 2015. 'Empowering the Kenyan people through alternative dispute resolution mechanisms', unpublished paper.

Killingray, D. 1986. 'The maintenance of law and order in British colonial Africa', African Affairs, 85(340):411-437.

LeVine, Robert A and LeVine, Barbara B. 1966. Nyansiongo: A Gusii community in Kenya. New York: Wiley.

Macfarlane, J. 2007. 'Working towards restorative justice in Ethiopia: Integrating traditional conflict resolution systems with formal legal system,' Cardozo Journal of Conflict Resolution, 8:487-509.

Maraga, D. K. 2016. Speech by Hon. Mr. Justice David Maraga, the Chief Justice of the Republic of Kenya, at the tribute proceedings in celebrating the 105 years of the legal fraternity in Kenya and the distinguished judicial careers of honourable Justice (RTD) John Mwera and honourable Justice Anyara Emukule on the $5^{\text {th }}$ of December, 2016.

Maxon, Robert M. 1989. Conflict and Accommodation in Western Kenya: the Gusii and the British. Rutherford: Failegh Dickson University Press

Mayer, I. 1965. "From kinship to common descent: Four generation genealogies among the Gusii”, Africa, Vol.35.

Mbiti, J. 1991. Introduction to African Religion. Oxford: Heinemann.

Meek, C.K. 1971. The Northern tribes of Nigeria. Frank Cass, London.

Milhizer, E.R. 2009. "So help me Allah: An historical and prudential analysis of oaths as applied to the current controversy of the Bible and Quran in oath practices in America", Ohio State Law Journal, Vol. 70:1, pp. 1-71.

Muigua, K., 2012. Resolving conflicts through mediation in Kenya, Nairobi: Glenwood Publishers Ltd.

Munge, B.N.; Ndeda, M. and Okuro, S.O. 2016. 'Emergence and growth of Kisii Town', Imperial Journal of Interdisciplinary Research (IJIR) 2(5):730-743

Murithi, T. 2006. "Practical Peace Making Wisdom from Africa: Reflections on Ubuntu." The Journal of Pan African Studies, 1(4): 25-34.

North, D.C. 1991. 'Institutions'. Journal of Economic Perspectives, 5(1): 97-112.

Ochieng,' W.R. 1974. A Pre-colonial history of the Gusii of Western Kenya; C.A.D 1500 to 1914. East African Literature Bureau, Nairobi. Ochieng', W.R. (1991): Themes in Kenya history (Ed.) Ohio University Press.

Onadeko, T. 2008. Yoruba traditional adjudicatory systems, African Study Monographs, 29(1): 15-28, March 2008

Onsongo, D. 2016. Traditional dispute resolution is justice, Daily Nation Newspaper, (accessed online at http://www.nation.co.ke/oped/Opinion/Traditional-dispute-resolution-is-justice/440808- 3407644msh95uz/).

Shaddle, B. 2006. "From 'traditional' to 'modern': African Court Elders in Nyanza Province, Kenya, c. 19301960." In Intermediaries, Interpreters, and Clerks, edited by Benjamin Lawrance, Emily Osborn, and Richard Roberts. Madison: University of Wisconsin Press. 
Silberschmidt, M. 1999. Women forget that men are the masters": Gender Antagonism and socio-economic change in Kisii District, Kenya. Elanders Gotab: Stockholm.

Tobiko, K. 2013. 'The relationship between formal rule of law and local traditional justice mechanism', A paper presented at the $18^{\text {th }}$ IAP Annual Conference and General Meeting, Moscow, Russia, $8^{\text {th }}-12^{\text {th }}$ September 2013.

Archival sources

Kenya National Archives, DP/1/13

Kenya National Archives, DP/18/13 administration, Minutes of law panel meetings 1938-61

Kenya National Archives, DC/KSI/1/2 South Kavirondo Administration annual report 1913-23

Oral interviews

Ezekiel Ochari (92 years) of Gucha South, Eyamarambe, etago, interviewed on $28^{\text {th }}$ December 2014 at noon.

Mzee Omoke (90 Years Old) Of Magenche Division, Kenyenya Sub-County, Interviewed On $27^{\text {th }}$ December 2014 at $3.00 \mathrm{Pm}$. 